Original Article

\title{
A Simple Liquid-Liquid Fractionation (LLF) Method for Isolating Deoxyandrographolide dan Andrographolide from Herbs of Andrographis paniculata (Burm., F) Ness and Its Cytotoxic Activity on 3T3-L1 Preadipocyte Cells
}

Putri Rachma Novitasari ${ }^{1}$, Novia Tri Astuti ${ }^{1}$, Raymond Tjandrawinata ${ }^{2}$, Suwijiyo Pramono ${ }^{3, *}$ and Agung Endro Nugroho ${ }^{4}$

1Master Program of Pharmaceutical Sciences, Faculty of Pharmacy, Universitas Gadjah Mada, Yogyakarta, 55281, Indonesia

${ }^{2}$ Dexa Laboratories of Biomolecular Sciences (DLBS), Cikarang, 17550, Indonesia

32Department of Pharmaceutical Biology, Faculty of Pharmacy, Universitas Gadjah Mada, Yogyakarta, 55281, Indonesia

4Department of Pharmacology and Clinical Pharmacy, Faculty of Pharmacy, Universitas Gadjah Mada, Yogyakarta, 55281, Indonesia

*Corresponding author: Suwijiyo Pramono | E-mail: suwijiyo_pramono@ugm.ac.id

Received: 26 October 2020; Revised: 22 November 2020; Accepted: 23 November 2020; Published: 31 December 2020

Abstract: The main bitter constituents of sambiloto (Androgaphis paniculata (Burm., F) Ness) are diterpene lactones, namely andrographolide and deoxyandrographolide which have been reported to have antidiabetic, cytotoxic, antiatherosclerosis, anti-inflammatory, and antimicrobial activity. There are many studies that performed the isolation of deoxyandrographolide and andrographolide from A. paniculata herbs, but most of them included several steps that make them not efficient. This research was conducted to do an isolation of deoxyandrographolide and andrographolide through liquid-liquid fractionation (LLF) due to its simplicity, low cost, and time efficient. The extraction of deoxyandrographolide and andrographolide from the herbs was carried out using chloroform as the solvent by using Soxhlet apparatus, and LLF was performed to isolate the compounds. The identities of the compounds were confirmed by TLC scanner compared to its standard references. Hence, these present methods were successfully isolated and determined deoxyandrographolide and andrographolide of $A$. paniculata. The compounds were also showed relatively moderate cytotoxicity on 3T3-L1 cell lines using 3-(4,5-dimethylthiazol-2-yl)-5-(3-carboxymethoxyphenyl)-2-(4-sulfophenyl)-2H-tetrazolium, inner salt (MTS) assay, with LC50 of deoxyandrographolide and andrographolide; $29.32 \mu \mathrm{g} / \mathrm{mL}$ and $37.70 \mu \mathrm{g} / \mathrm{mL}$, respectively.

Keywords : Andrographis paniculata, isolasi, Fraksinasi Cair-Cair, 3T3-L1, MTS

\section{INTRODUCTION}

In recent years, treatment of diseases with traditional herbs has become an alternative. The main reasons regarded as relatively safe in long term use and it has minimal side effects. Andrographis paniculata (Burm.f.) Nees is known as a medicinal plant which can be used as an alternative treatment for various diseases. It is known as king of bitter due to the very bitter taste of all part of the plant and in Indonesia its name is sambiloto. In pharmacological research, it shows antidiabetic [1], 
cytotoxic effect [2], antimicrobial activity [3], anti-inflammatory [4], anti-hyperglycemia [5], antiatherosclerosis [6], antimalaria [7], hepatoprotective [8], and anticancer activity [9]; in vitro and in vivo studies.

The phytochemical contents of $A$. paniculata include diterpenoids, polyphenols and flavonoids [10]. Andrographolide $\left(\mathrm{C}_{20} \mathrm{H}_{30} \mathrm{O}_{5}\right)$ is the first major diterpene lactone. Andrographolide exhibits several pharmacological properties and a potential chemotherapy agent [11]. Andrographolide contains $\alpha$-alkylidene $\gamma$-butyrolactone and three hydroxyl groups in C-3, C-19 and C14 (Fig.1) which are responsible for cytotoxic activity against many cancer cells [11].

Several methods of isolation deoxyandrographolide and andrographolide compounds from sambiloto have been carried out. Isolation of deoxyandrographolide has been evaluated by several methods, including not only the methods by Rashid et al., 2018 and Hermawan et al., 1997 using Preparative Thin Layer Chromatography (PTLC), but also the method by Imanta, 2017 [12-14]. Isolation of deoxyandrographolide has been performed by Rashid et al., 2018 from ethanolic crude extract which then was subjected to silica gel column chromatography eluted with chloroformmethanol (99:1) [12]. More than 20 years ago Hermawan et al., 1997 isolated deoxyandrographolide using Preparative Thin Layer Chromatography (PTLC) [13]. Chromatographic methods were needed not only for isolation of deoxyandrographolide but also for separation of andrographolide and deoxyandrographolide. Isolation of andrographolide has been reported from cold maceration of leaf powder in a 1:1 mixture of dichloromethane and methanol followed by recrystallization [15]. The second major diterpene lactone of A. paniculata is 14-deoxyandrographolide (Fig. 1). It has immunomodulatory and antiatherosclerotic effects $[16,17]$. Therefore, the chosen isolation method must be selective to provide the expected isolation results precisely and quickly. This research focused on the isolation of deoxyandrographolide and andrographolide from the herbs of $A$. paniculata without chromatographic method. So, this research became a new thing to separate andrographolide and deoxyandrographolide.

On the other hand, the use of A. paniculata as remedy for curing diabetes is usually in relatively long period of time, so a question of safety arrises. Beside the chronic toxicity test, the approach of safety concern can be performed by observation of cytotoxicity. Based on this approach, this research focused also on the effect of deoxyandrographolide and andrographolide on viability of pre-adipocyte cells.

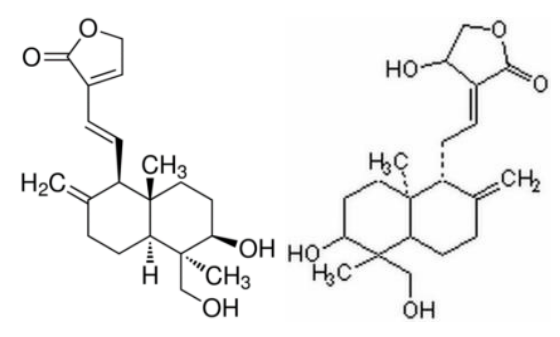

Figure 1. Chemical structure of deoxyandrographolide and andrographolide

\section{MATERIALS AND METHODS}

\subsection{Materials}

The herbs of A. paniculata were collected during April 2019 from Kulonprogo Region of Yogyakarta Province, Indonesia. Authentication of herb was conducted by a botanist at Department of Pharmaceutical Biology, Faculty of Pharmacy, Universitas Gadjah Mada, Indonesia and the 
voucher specimen were kept in herbarium of that department. The high glucose of Dulbecco's Modified Eagle Medium (DMEM), bovine serum (BS), and Penicillin/Streptomycin were purchased from Gibco (Gaithersburg, USA), whereas Dimethyl Sulfoxide (DMSO), andrographolide and deoxyandrographolide standard references were obtained from Sigma Aldriech. Pro analysis degree of silica gel plate, chloroform, $n$-hexane, ethyl acetate and methanol were obtained from Merck. 3T3L1 fibroblast cells were procured from American Culture Collection (ATCC) (Manassas, VA).

2.2. Liquid-Liquid Fractionation (LLF) Method for Isolation of 14-deoxyandrographolide and andrographolide

Briefly, the chloromic extract, the non-hexanic fraction, the isolated andrographolide and deoxyandrographolide were applied on silica gel $F_{254}$ HPTLC plate with $n$-hexane: ethyl acetate (1:4) $\mathrm{v} / \mathrm{v}$ as mobile phase and detected under ultraviolet lamp $254 \mathrm{~nm}$. The authentication of isolated andrographolide and deoxyandrographolide was checked by comparison with their standard references on HPTLC system. Therefore, the pattern spectrums of each isolates were compared to each standard reference.

\subsection{Cell Culture}

3T3-L1 fibroblast cells were cultured in high glucose DMEM supplemented with 10\% bovine serum $(10 \% \mathrm{~B} / \mathrm{S}), 1 \%$ penicillin/streptomycin $(1 \% \mathrm{P} / \mathrm{S})]$ and incubated at $37^{\circ} \mathrm{C}$ in a condition of humidified atmosphere of $5 \% \mathrm{CO}_{2}$. Cells were sub-cultured every 2-3 days at confluence at approximately $90 \%$.

\subsection{Cytotoxicity Test of Deoxyandrographolide and Andrographolide on 3T3-L1 Pre-adipocyte Cells}

Deoxyandrographolide and andrographolide were tested on 3T3-L1 pre-adipocyte cells based on the previous studies by Tandrasasmita et al., 2011 with any modifications [18]. The aim of this method was to examine the safety concentration of the deoxyandrographolide and andrographolide on 3T3-L1 pre-adipocyte cells. The first step, we should make a standard curve of the cells to convert the cells number in a toxicity cells curve. 3T3-L1 pre-adipocyte cells were platting in 96-well plate. Series cells curve that was made has the concentration of $1 \times 10^{4}, 3 \times 10^{4}, 5 \times 10^{4}, 7 \times 10^{4}$, $9 \times 10^{4}$, and $1 \times 10^{5} \mathrm{cell} / \mathrm{mL}$ in DMEM+1\% P/S 1\%+10\% B/S. There were incubated in 12 hours (to avoid doubling time of cells) in $37^{\circ} \mathrm{C}, 5 \% \mathrm{CO}_{2}$. Thereafter, cells were observed with microscope. The medium was changed to $100 \mu \mathrm{L}$ PBS 1x, then it was added by $20 \mu \mathrm{L}$ MTS reagent. The mixture was then incubated in $37^{\circ} \mathrm{C}, 1$ hour 30 minutes. From these steps, the equation of the lines would be concluded.

The cytotoxicity of deoxyandrographolide and andrographolide were examined by 3-(4,5dimethylthiazol-2-yl)-5-(3-carboxymethoxyphenyl)-2-(4-sulfophenyl)-2H-tetrazolium, inner salt (MTS) assay. Briefly, 3T3-L1 pre-adipocyte cells were cultured in 96-well plate until the confluence of 5x104 cells $/ \mathrm{mL}$ in high glucose DMEM+1\% P/S $1 \%+10 \% \mathrm{~B} / \mathrm{S}$. Cells were incubated in 24 hours, $37^{\circ} \mathrm{C}, 5 \%$ $\mathrm{CO}_{2}$. Cells were then observed microscopically. Thereafter, cell became $80 \%$ confluence, the medium was changed to high glucose DMEM free serum, and it was incubated until 4 hours, $37{ }^{\circ} \mathrm{C}, 5 \% \mathrm{CO}_{2}$. After incubated for 4 hours, the high glucose DMEM free serum was discarded and then it was treated by deoxyandrographolide with the doses $2.5,5,10,12.5,25,50,75$ and $100 \mu \mathrm{g} / \mathrm{mL}$ in $0,1 \%$ DMSO. Whereas the dose of andrographolide for the treatment were 3.125, 6.25, 12.5, 25, 50,75 and $100 \mu \mathrm{g} / \mathrm{mL}$ in $0,1 \%$ DMSO. The mixtures were incubated in $37^{\circ} \mathrm{C}, 5 \% \mathrm{CO}_{2}$ until 24 hours. The media 
was changed to $100 \mu \mathrm{L}$ PBS $1 x$, then it was added by $20 \mu \mathrm{L}$ MTS. Cells were incubated in $37^{\circ} \mathrm{C}, 1$ hour 30 minutes. The LC 50 in standard cells curve was analyzed by probit analyze in Biostat v5 software.

\subsection{Statistical Analysis}

Data were statistically analyzed using IBM PASW SPSS Statistic version 18.0 (SPSS IBM, NY USA). Normality test were conducted using Saphiro Wilk. Statistical significance $(p<0.05)$ was assessed by one-way analysis of variance (ANOVA) coupled with Dunnett's T-tests.

\section{RESULT AND DISCUSSION}

\subsection{Isolation of Deoxyandrographolide and Andrographolide}

Extraction of A. paniculata herbs using Soxhlet apparatus gave a result of $8.26 \mathrm{~g}$ crude extract with dark green color, whereas the Liquid-Liquid Fractionation (LLF) method was successfully isolated the deoxyandrographolide and andrographolide from the extracts. Firstly the fractionation with $n$-hexane eliminated perfectly chlorophyl and other lypophilic substances without interfere deoxyandrographolide and andrographolide such as shown by HPTLC data (Fig. 2). Further, as we know that in comparison to andrographolide, deoxyandrographolide lack of oxygene moiety at 14 position in the structure (Fig. 1). That will increase lyphophilicity of the structure and we found that the mixture of n-hexane: chloroform (3:2) dissolved deoxyandrographolide but not andrographolide. The last mentioned compound was dissolved in chloroform. Both deoxyandrographolide and andrographolide were then recrystallized and the crystals had white color. Thus, LLF was chosen for this experiment due to its simplicity, low cost, and time efficient. A simple LLF method has been developed for the isolation of deoxyandrographolide and andrographolide from chloroformic extract of A. paniculata. As the isolate was formed, the weight of deoxyandrographolide and andrographolide were measured and showed yields of $0.248 \mathrm{~g}$ and $0.502 \mathrm{~g}$ respectively, or $3.0 \%$ and $6.07 \%$ from chloroformic extract. In comparison to other publication that the percentage of deoxyandrographolide in ethanol extract of dried whole plant, stems and herbs were $4 \%, 0.8-1.2 \%$ and $0.5-6 \%$, respectively [19]. Indonesian Herbal Pharmacopoea mentions the percentage of andrographolide in ethanolic extract of $A$. paniculata herbs are not more than $3.80 \%$ [20]. The percentage of isolated deoxyandrographolide and andrographolide from chlorofomic extract in this research are relatively higher than ethanolic extract mentioned in the litterature due to lower percentage of polar impurities. As we know that ethanol is an universal or non selective solvent. It dissolves lypophylic and hydrophylic substances whereas chloroform dissolves only lyphophylic ones.

In this study, deoxyandrographolide and andrographolide appeared on silica gel $\mathrm{F}_{254}$ as quenching spots under UV254 at Rf value 0.66 and 0.38, respectively (Fig.2) These spots are not only similar to those of standard references, the pattern of spectrums are also similar to those of standard references according to the data evaluated by TLC scanner (Fig.3). 


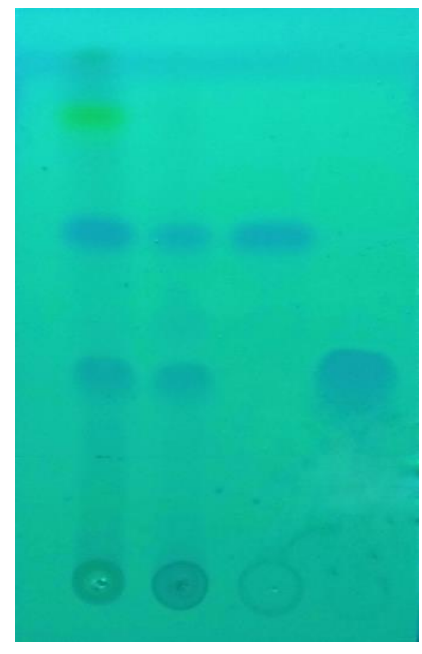

A $\quad$ B $\quad$ C $\quad$ D

Figure 2. HPTLC silica gel 254 profile of A. paniculata herbs. A: Chloroformic extract, B: n-Hexanic unsoluble fraction, C: Isolated deoxyandrographolide, D: Isolated andrographolide. Mobile phase: n-Hexane-Ethyl acetate $(1: 4)$
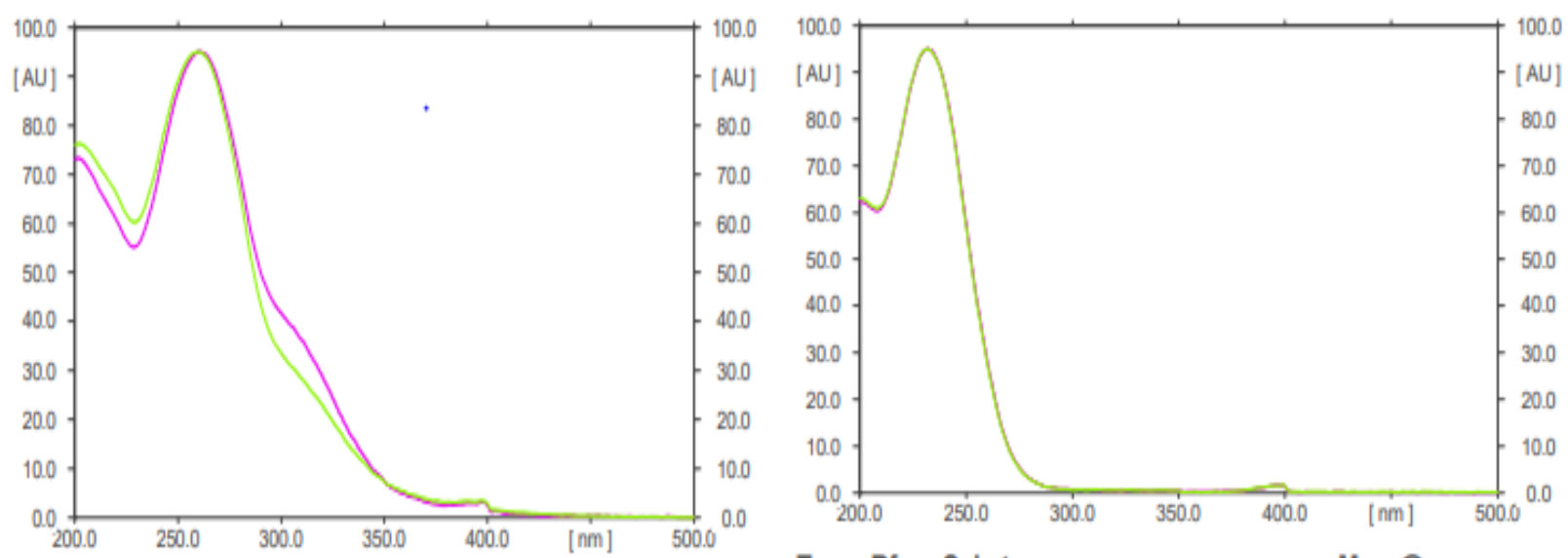

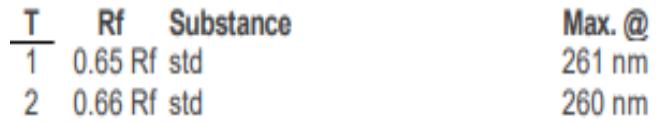

$\begin{array}{ccc}\frac{T}{T} & \begin{array}{cl}\text { Rf } \\ \text { N Substance }\end{array} & \text { Max. @ } \\ 2 & 0.38 \mathrm{Rf} \text { std } & 232 \mathrm{~nm} \\ 2 & 0.38 \mathrm{Rf} \text { std } & 232 \mathrm{~nm}\end{array}$

Figure 3. UV Spectrum profiles of isolated deoxyandrographolide with standard reference and andrographolide with standard reference

\subsection{Cytotoxicity Test Result of Deoxyandrographolide and Andrographolide on 3T3-L1 Pre-adipocyte Cells}

Further study was designed to examine the cytotoxic effect of deoxyandrographolide and andrographolide on 3T3-L1 pre-adipocyte cells. The equation of standard curve cells was $y=2063 x-$ 545.69. This equation was important because it was to convert the number of cells. Fig. 4 showed exemples of microscopic view of cells of the control group treated with DMSO and the group treated with deoxyandrographolide $50 \mu \mathrm{g} / \mathrm{mL}$. Almost all cells of the control group without any treatment except the media were 3126 cells, whereas after treatment with 5.0, 10.0 and $12.5 \mu \mathrm{g} / \mathrm{mL}$ of deoxyandrographolide the viability of cells were lower than the control, and then the viability decrease significantly at the concentration of $25 \mu \mathrm{g} / \mathrm{mL}$ and at concentration more than $50 \mu \mathrm{g} / \mathrm{mL}$ all cells were death. It means that $12.5 \mu \mathrm{g} / \mathrm{mL}$ were limit of concentration which did not influence significant viability of cells (Fig. 5). Thus, the cell viability was dramatically increased (almost 100\%) 
upon 2,5 ug/ml deoxyandrographolide treatment (Fig. 5), it was because in that dose could be happen proliferation cells. The viability of cells without any treatment except the media were 2720 cells, whereas after treatment with $3.125,6.25$, and $12.5 \mu \mathrm{g} / \mathrm{mL}$ of andrographolide the viability of cells were still upper than the control. At the concentration of $25 \mu \mathrm{g} / \mathrm{mL}$ the viability of cells were lower than the control, and than the viability decrease significantly at the concentration of $50 \mu \mathrm{g} / \mathrm{mL}$ and at concentration more than $75 \mu \mathrm{g} / \mathrm{mL}$ all cells were death, so the concentration of $25 \mu \mathrm{g} / \mathrm{mL}$ was limit of concentration which did not influence significant viability of cells (Fig, 6). It meaned that for further experiment the use of $12.5 \mu \mathrm{g} / \mathrm{mL}$ deoxyandrographolide would be safe, whereas the safe concentration of andrographolide were $25 \mu \mathrm{g} / \mathrm{mL}$. The $\mathrm{LC}_{50}$ value was calculated from the correlation between percentage of death cells with the concentration using probit analysis according to Biostat Pro 5.9.8 software. The LC50 value of deoxyandrographolide and andrographolide was counted to see the effect of each isolates which was represent the $50 \%$ the death of cells. These were $29.32 \mu \mathrm{g} / \mathrm{mL}$ and $37.70 \mu \mathrm{g} / \mathrm{mL}$, respectively. The statistical data of ANOVA showed that both isolates were significant compared to DMSO as control group $(\mathrm{p}<0.05)$. That was important to give not only the information about cytotoxic activity but also the cell viability for the next in vitro experiment.
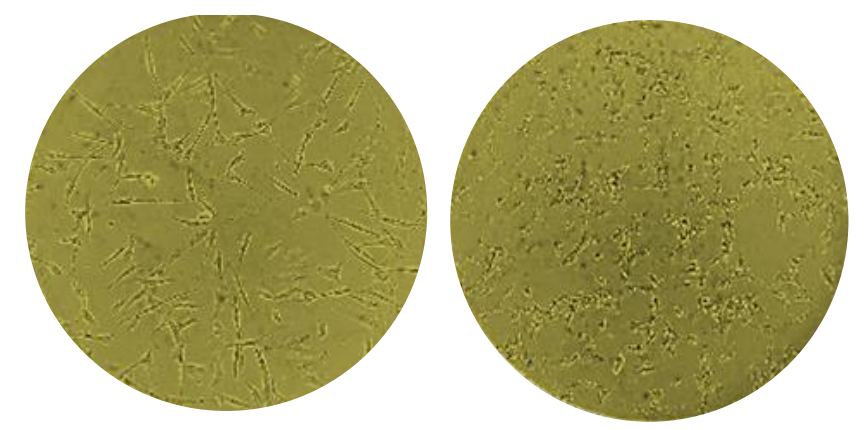

Figure 4. Microscopic view of 3T3-L1 pre-adipocyte cells after treatment with DMSO (control group) and deoxyandrographolide $50 \mu \mathrm{g} / \mathrm{mL}$

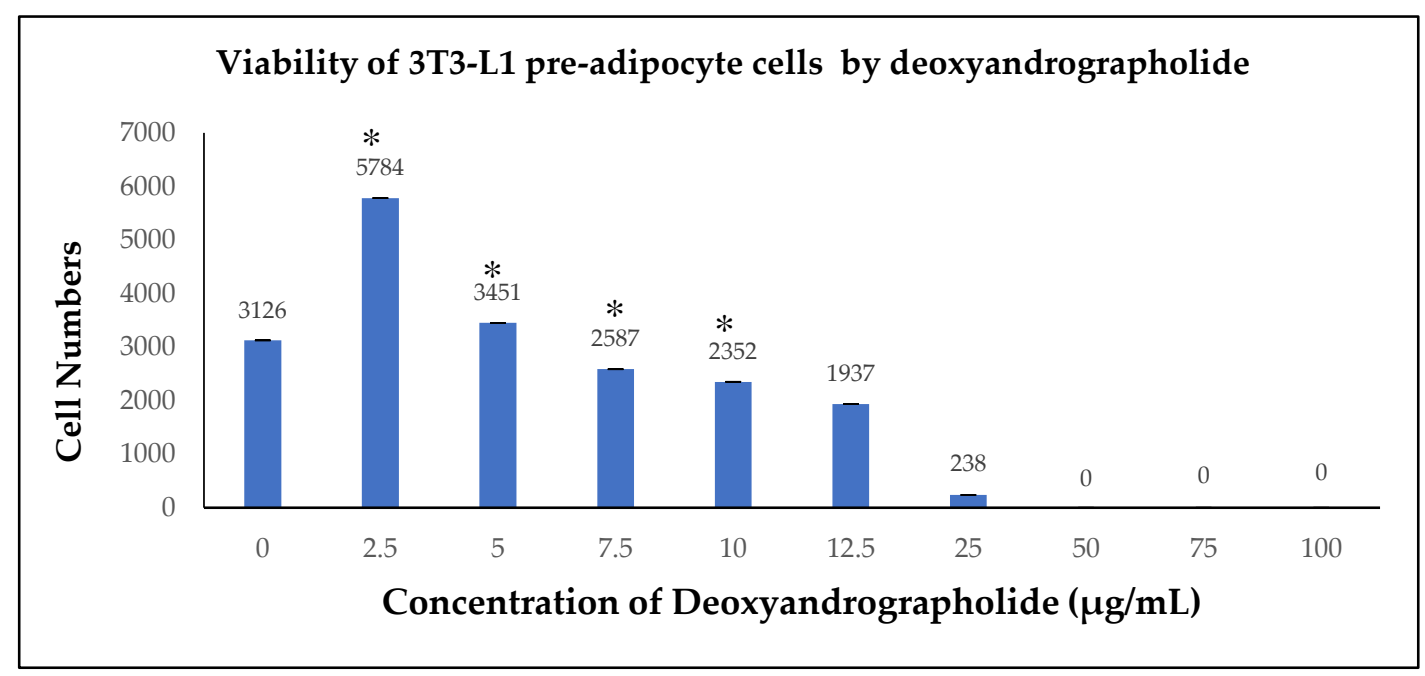

Figure 5. Viability of 3T3-L1 pre-adipocyte cells after treatment different concentration of deoxyandrographolide (average $\pm S D, n=3$ ). Information: ${ }^{*}$ ) Significant difference result $(\mathrm{p}<0,05)$ compared to control 


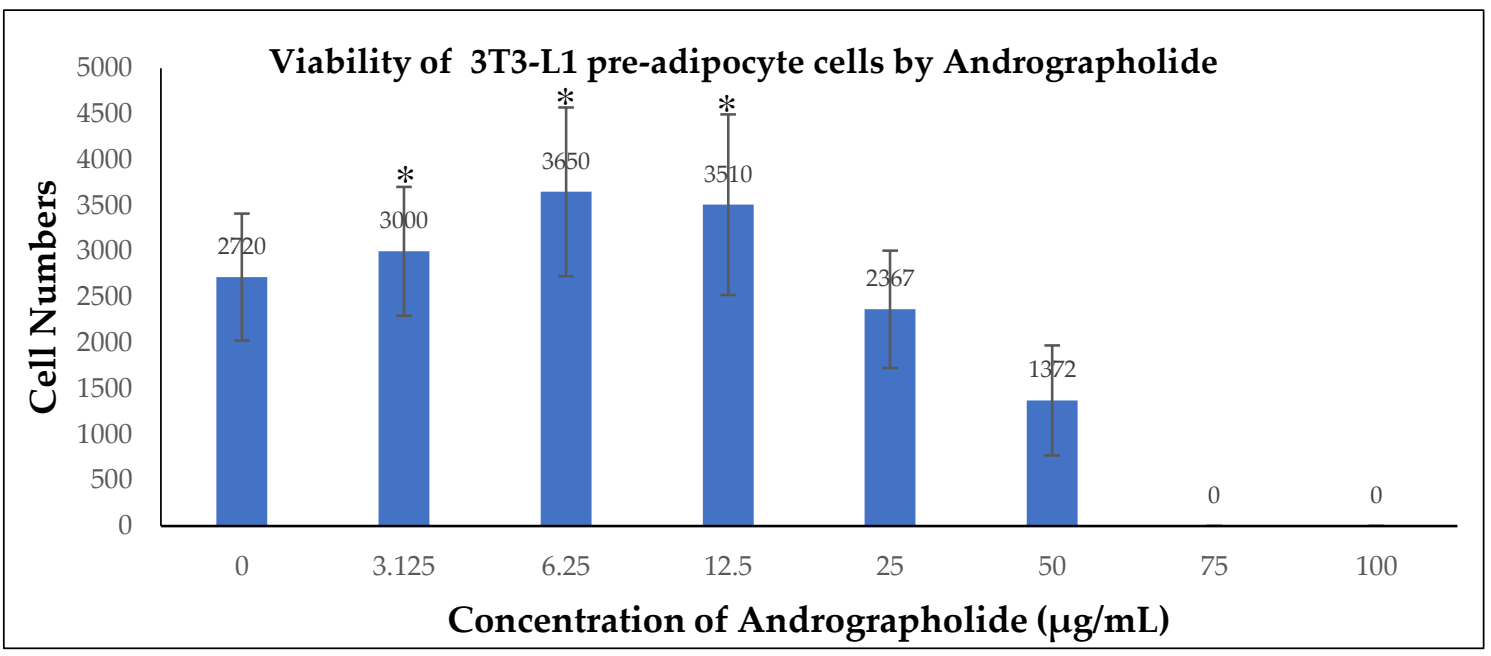

Figure 6. Viability of 3T3-L1 pre-adipocyte cells after treatment with different concentration of andrographolide (average $\pm S D, n=3)$. Information: $\left(^{*}\right)$ Significant difference result $(p<0,05)$ compared to control

\section{CONCLUSION}

By this study, we have evaluated the lilquid-liquid fractionation method for isolating deoxyandrographolide and andrographolide from A. paniculata herbs. The method was found to be suitable for analysis because its simplicity, low cost, and time efficient. The cytotoxicity of deoxyandrographolide and andrographolide on 3T3-L1 pre-adipocyte cells was also evaluated and the $\mathrm{LC}_{50}$ were 29.32 and $37.70 \mu \mathrm{g} / \mathrm{mL}$, respectively.

Acknowledgements: We thank to Dexa Laboratories of Biomolecular Sciences (DLBS) for provision of research facilities. Great appreciation is also addressed to Direktorat Peneliti UGM through "Hibah Program Asistensi Riset 2019" for the financial support of the research.

Conflict of interest: There is no conflict of interest.

\section{Reference}

1. Fitrawan L, Ariastuti R, Tjandrawinata RR, Nugroho AE, Pramono S. Antidiabetic effect of combination of fractionated-extracts of Andrographis paniculata and Centella asiatica: In vitro study. Asian Pacific Journal of Tropical Biomedicine, 2018, 8(11):527.

2. Tan ML, Kuroyanagi M, Sulaiman SF, Najimudin N, Muhammad TST. Cytotoxic Activities of Major Diterpenoid Constituents of Andrographis paniculata. in a Panel of Human Tumor Cell Lines. Pharmaceutical Biology [Internet]. 2005 [cited 2019 Sep 15];43(6):501-8. Available from: https://doi.org/10.1080/13880200500220557

3. Xu Y, Marshall RL, Mukkur TKS. An investigation on the antimicrobial activity of Andrographis paniculata extracts and Andrographolide in vitro. Asian Journal of Plant Sciences, 2006, 5(3):527-30.

4. Ww C, Yh K, Sl H, Bf L. Inhibitory Effects of Ethyl Acetate Extract of Andrographis paniculata on NF-kB Trans-Activation Activity and LPS-Induced Acute Inflammation in Mice. Evid Based Complement Alternat Med, 2011, 254531-254531. 
5. Thakur AK, Rai G, Chatterjee SS, Kumar V. Beneficial effects of an Andrographis paniculata extract and andrographolide on cognitive functions in streptozotocin-induced diabetic rats. Pharm Biol. 2016, 54(9):1528-38.

6. Al Batran R, Al-Bayaty F, Al-Obaidi MMJ, Hussain SF, Mulok TZ. Evaluation of the Effect of Andrographolide on Atherosclerotic Rabbits Induced by Porphyromonas gingivalis [Internet]. BioMed Research International. 2014 [cited 2019 Dec 18]. Available from: https://new.hindawi.com/journals/bmri/2014/724718/

7. Widyawaruyanti A, Asrory M, Ekasari W, Setiawan D, Radjaram A, Tumewu L, et al. In vivo Antimalarial Activity of Andrographis Paniculata Tablets. Procedia Chemistry. 2014, 13:101-4.

8. Mishra N, Yadav KS, Rai VK, Yadav NP. Polysaccharide Encrusted Multilayered NanoColloidal System of Andrographolide for Improved Hepatoprotection. AAPS PharmSciTech. 2017, 18(2):381-92.

9. Sukardiman H, Widyawaruyanti A, Sismindari null, Zaini NC. Apoptosis inducing effect of andrographolide on TD-47 human breast cancer cell line. Afr J Tradit Complement Altern Med. 2007, 4(3):345-51.

10. Chao W-W, Lin B-F. Isolation and identification of bioactive compounds in Andrographis paniculata (Chuanxinlian). Chin Med. 2010, 13;5:17.

11. Varma A, Padh H, Shrivastava N. Andrographolide: A New Plant-Derived Antineoplastic Entity on Horizon [Internet]. Evidence-Based Complementary and Alternative Medicine. 2011 [cited 2020 Sep 2]. Available from: https://www.hindawi.com/journals/ecam/2011/815390/

12. Rashid P, Ahmed M, Rahaman, Muhit M. 14-Deoxyandrographolide Isolated from Andrographis paniculata (Burm. f) Nees Growing in Bangladesh and its Antimicrobial Properties. Dhaka University Journal of Pharmaceutical Sciences. 2018, 17:265.

13. Hermawan W, Nakajima S, Tsukuda R, Fujisaki K, Nakasuji F. Isolation of an Antifeedant Compound from Andrographis paniculata (Acanthaceae) against the Diamondback Moth, Plutella xylostella (Lepidoptera: Yponomeutidae). Applied Entomology and Zoology. 1997, 32(4):551-9.

14. Imanta E. Uji Biolarvasida Nyamuk Aedes aegypty dari Hasil Isolasi Ekstrak Metanol Tanaman Sambiloto (Andrographis paniculata NESS). Unesa Journal of Chemistry [Internet]. 2017 May 8 [cited 2020 Aug 9];6(1).Available from:https://jurnalmahasiswa.unesa.ac.id/index.php/unesajournal-of-chemistry/article/view/19068.

15. Rajani M, Shrivastava N, Ravishankara MN. A rapid method for isolation of andrographolide from andrographis paniculata nees (kalmegh). Pharm Biol. 2000, 38(3):204-9.

16. Zhang CY, Tan BKH. Vasorelaxation of Rat Thoracic Aorta Caused by 14Deoxyandrographolide. Clinical and Experimental Pharmacology and Physiology, 1998, 25(6):424-9.

17. Ra B, M L, Ma H, Tp L, Jl H. Effect of 14-deoxyandrographolide on calcium-mediated rat uterine smooth muscle contractility. Phytother Res, 2003, 17(9):1011-5. 
18. Tandrasasmita OM, Wulan DD, Nailufar F, Sinambela J, Tjandrawinata RR. Glucose-lowering effect of DLBS3233 is mediated through phosphorylation of tyrosine and upregulation of PPAR $\gamma$ and GLUT4 expression. Int J Gen Med. 2011, 4:345-57.

19. Cheung HY, Cheung CS, Kong CK. Determination of bioactive diterpenoids from Andrographis paniculata by micellar electrokinetic chromatography. Journal of Chromatography A. 2001, 930(1):171-6.

(C) 2020 by the authors. Submitted for possible open access publication under the terms and conditions of the Creative Commons Attribution (CC BY) license (http://creativecommons.org/licenses/by/4.0/). 